\title{
Relationships between cheese-processing conditions and curd and cheese properties to improve the yield of Idiazabal cheese made in small artisan dairies: A multivariate approach
}

\author{
Ane Aldalur, ${ }^{1,2} \odot$ María Ángeles Bustamante, ${ }^{1,2}$ ๑ Jesús Salmerón, ${ }^{2} \odot$ and Luis Javier R. Barron ${ }^{1,2 *} \odot$ \\ ${ }^{1}$ Lactiker Research Group, University of the Basque Country (UPV/EHU), Paseo de la Universidad 7, 01006 Vitoria-Gasteiz, Spain \\ ${ }^{2}$ Department of Pharmacy and Food Sciences, Faculty of Pharmacy, University of the Basque Country (UPV/EHU), Paseo de la Universidad 7 , \\ 01006 Vitoria-Gasteiz, Spain
}

\begin{abstract}
Very diverse cutting and cooking intensity processes are currently used in small artisan dairies to manufacture Idiazabal cheese. The combination of the technical settings used during cheese manufacturing is known to affect cheese composition and yield, as well as whey losses. However, the information regarding the effect on microstructure and texture of cheese is scarce, especially in commercial productions. Therefore, the effect of moderate- and high-intensity cutting and cooking processes on whey losses, curd-grain characteristics, microstructure and cheese properties, and yield were analyzed. Three trials were monitored in each of 2 different small dairies during the cheesemaking of Idiazabal cheese, which is a semihard cheese made from raw sheep milk. The role and know-how of the cheesemakers are crucial in these productions because they determine the cutting point and handle semi-automatic vats. The 2 dairies studied used the following settings: dairy A used moderate-intensity cutting and cooking conditions, and dairy B used high-intensity cutting and cooking settings. Multiple relationships between cheese-processing conditions and curd, whey, and cheese properties as well as yield were obtained from a partial least square regression analysis. An increased amount of fat and casein losses were generated due to a combination of an excessively firm gel at cutting point together with high-intensity cutting and cooking processes. The microstructural analysis revealed that the porosity of the protein matrix of curd grains after cooking and cheese after pressing was the main feature affected, developing a less porous structure with a more intense process. Moderate-intensity cutting and cooking processes were associated with a higher cheese yield, regardless of the longer pressing process applied. No significant differ-
\end{abstract}

Received May 20, 2020.

Accepted August 13, 2020.

*Corresponding author: luisjavier.rbarron@ehu.eus ences were observed in cheese composition. After 1 mo of ripening, however, the cheese was more brittle and adhesive when the high-intensity cutting and cooking process was applied. This could be associated with the composition, characteristics, and size distribution of curd grains due to differences in the compaction degree during pressing. These results could help to modify specific conditions used in cheesemaking, especially improving the process in those small dairies where the role of the cheesemaker is crucial.

Key words: cheese yield, whey losses, curd-grain size, microstructure, cheese texture

\section{INTRODUCTION}

The technical settings and equipment used during cheesemaking directly affect cheese yield, whey losses, and cheese and curd-grain properties. In dairies where the cheese production is not completely automated, the control of the technical conditions and the role of the cheesemaker are especially important. A recent study analyzed the manufacturing conditions used in Idiazabal cheesemaking carried out in artisan dairies, and the interactions between these conditions and cheese yield, composition, and whey losses (Aldalur et al., 2019c). The results highlighted the variety of coagulation, cutting, and cooking settings used among dairies to produce the same type of cheese. The diversity in the technical settings also affected the cheese yield, component losses in the drained whey, and curd-grain characteristics. Fat losses were enhanced by insufficient or excessive cutting processes followed by high stirring speeds, while cheese yield was impaired with longer cutting and cooking times and higher cooking temperatures.

Choosing the optimal cutting point, which is defined as the moment that the cutting process starts, is a crucial step to avoid fat and casein losses (Lucey, 2011). Cutting the coagulated curd mass when it is too firm causes higher component losses in the whey during the manufacturing of semihard cheeses (Kammerlehner, 
2009). Additionally, the time, speed, and their combination used during cutting and cooking processes also have a remarkable effect on component losses. On one hand, an excessive cutting step, either for a long process, a high speed, or both has been reported to increase whey losses (Kammerlehner, 2009; Aldalur et al., 2019b). On the other hand, the combined effect of an insufficient cutting process followed by higher stirring speed settings enhances fat and casein losses (Johnston et al., 1998; Everard et al., 2008). Some authors suggest that carrying out a healing step, where the curd grains are left undisturbed after cutting, could help to reduce fat losses (Riddell-Lawrence and Hicks, 1988). The development of a skin in the outside of the curd grains during this period would reduce the fragility of the curd grains and help to retain more fat globules in the protein matrix.

The cutting and cooking technical settings also affect the properties of the curd grains (Aldalur et al., 2019a), and thus their deformation capacity during pressing (Akkerman et al., 1996). It has been suggested that the deformation capacity of curd grains could have an important effect on the curd fusion during pressing, consequently affecting the texture of the cheese (Fagan et al., 2017). Moreover, the size distribution of curd particles has been reported to be heterogeneous in artisanal dairies (Iezzi et al., 2012; Aldalur et al., 2019a), and this could cause moisture distribution problems and defects in the cheese texture.

Microstructure greatly changes during the cheesemaking process, developing with the course of the process. Confocal laser scanning microscopy (CLSM) allows for observation and quantification in 3 dimensions of the changes in casein compaction and fat globule conformation, which could have further implications in the texture and flavor of cheese (Everett and Auty, 2017). Recently, it has been suggested that curd-grain size could be related to a higher nonglobular fat amount due to a higher level of compaction during pressing (Aldalur et al., 2019b). Additionally, cheese texture is determined by its microstructure and physicochemical composition (Lamichhane et al., 2018), but the effect of in-vat cheesemaking settings on microstructure and texture has not been widely reported.

The aim of this work was to study the effect of 2 cheesemaking processes that highly differed in their cutting, cooking, and pressing steps on cheese yield, microstructure, and texture as well as component losses in the whey. The cheese manufacturing procedures were defined as moderate and high for dairy $\mathrm{A}$ and $\mathrm{B}$, respectively, depending mainly on the combination of speed and time used during the cutting and cooking steps. Additionally, curd-grain microstructure and whey losses after cutting and cooking were studied to assess (1) the difference between the 2 dairies and (2) the effect of a high or moderate-intensity process during syneresis within the same dairy.

\section{MATERIALS AND METHODS}

\section{Commercial Cheese Productions and Sampling}

Two small dairies that manufacture Idiazabal protected designation of origin (PDO) cheese were selected for the study. Dairy A used moderate-intensity cutting and cooking conditions together with a longer pressing process. Dairy B used high-intensity cutting and cooking settings together with a shorter pressing process. Table 1 shows the main technological settings used for cheese production by the small dairies, with the average values defined as moderate and high intensity for the cutting and cooking processes throughout this text. Both dairies used milk from their own flocks for the cheesemaking, and shepherds managed their flocks in a comparable way, resulting in a quite similar milk composition (Table 2). Dairy A used an open doubleO shaped vat equipped with 2 vertical cutting frames with a $6 \mathrm{~cm}$ separation of the knives from each another. These were turned into stirrers when the direction of the rotation was inverted. Dairy B used an open ovalshaped vat with 2 vertical cutting frames with a wire separation of $2 \mathrm{~cm}$ from each another. Two irregular shaped stirrers were placed for stirring the mixture of whey and curd grains during the cooking process. Three cheese productions were carried out for each dairy in 3 consecutive weeks from late May to early June. In short, the experimental design consisted of 1 factor at 2 levels (dairy A and dairy B) with 3 replicated blocks (n $=3$ ). During the monitoring of the cheese processing, several physicochemical variables such as temperatures, times, cutting and stirring speed, pressing force, relative humidity of chambers, milk, curd and whey $\mathrm{pH}$, or cheese weight were measured in situ as described in Aldalur et al. (2019c).

The commercial cheeses were made with bulk raw sheep milk and followed the Idiazabal PDO bid specification (Ministerio de Agricultura, Pesca, y Alimentación, 1993). Briefly, a commercial homofermentative lyophilized starter culture (mixture of Lactococcus lactis ssp. lactis and Lactococcus lactis ssp. cremoris strains; Choozit MA16LYO 25 DCU, DuPont NHIB Ibérica S.L., Barcelona, Spain) was added directly to the vat when milk was at $25^{\circ} \mathrm{C}$, and temperature was increased to $\sim 30^{\circ} \mathrm{C}$ while stirring. Artisanal lamb rennet paste was added and the mixture was blended. The cheesemaker decided the cutting point (based on their experience and know-how) when the coagulated milk was cut with a knife and it showed specific characteristics. 
Table 1. Technical conditions (mean $\pm \mathrm{SD})$ used during cheese manufacturing $(\mathrm{n}=3)$ for moderate- (dairy A) and high-intensity (dairy B) cutting and cooking processes in Idiazabal PDO cheese production in small dairies

\begin{tabular}{|c|c|c|}
\hline Item & Dairy A & Dairy B \\
\hline Amount of milk $(\mathrm{kg})$ & $1,192 \pm 63^{\mathrm{a}}$ & $678 \pm 52^{\mathrm{b}}$ \\
\hline Storage temperature ${ }^{1}\left({ }^{\circ} \mathrm{C}\right)$ & 5.0 & 6.0 \\
\hline Storage time ${ }^{1}(\mathrm{~h})$ & 60 & 15 \\
\hline Coagulation temperature $\left({ }^{\circ} \mathrm{C}\right)$ & $29.3 \pm 0.6^{\mathrm{b}}$ & $31.0 \pm 0.0^{\mathrm{a}}$ \\
\hline Coagulation $\mathrm{pH}$ & $6.50 \pm 0.04$ & $6.51 \pm 0.02$ \\
\hline Coagulation time (min) & $50 \pm 5^{\mathrm{a}}$ & $34 \pm 1^{\mathrm{b}}$ \\
\hline Rennet concentration $^{1}(\mathrm{~g} / 100 \mathrm{~L}$ of milk) & 0.15 & $\begin{array}{c} \pm 1 \\
0.12\end{array}$ \\
\hline Milk-clotting activity $^{2}$ (rennet unit/g of rennet) & 63.07 & 149.79 \\
\hline Gel-compression work $(\mathrm{g} \cdot \mathrm{s})$ & $844 \pm 19$ & $923 \pm 94$ \\
\hline Cutting temperature $\left({ }^{\circ} \mathrm{C}\right)$ & $30.3 \pm 0.6$ & $31.0 \pm 0.0$ \\
\hline Cutting pH & $6.50 \pm 0.07$ & $6.49 \pm 0.01$ \\
\hline Cutting time ( $\min )$ & $12 \pm 1^{\mathrm{b}}$ & $28 \pm 7^{\mathrm{a}}$ \\
\hline Cutting speed (rpm) & $8.4 \pm 1^{\mathrm{b}}$ & $22.1 \pm 0.3^{\mathrm{a}}$ \\
\hline Cutting tip speed $(\mathrm{m} / \mathrm{min})$ & $71.5 \pm 8.8^{\mathrm{b}}$ & $100.7 \pm 1.2^{\mathrm{a}}$ \\
\hline Cutting revolutions (rev) & $101 \pm 16^{\mathrm{b}}$ & $611 \pm 144^{\mathrm{a}}$ \\
\hline Cutting process ${ }^{3}\left(\mathrm{~m} \cdot\right.$ number wires $\left./ \mathrm{m}^{2}\right)$ & $23,768 \pm 3812^{\mathrm{b}}$ & $189,321 \pm 44691^{\mathrm{a}}$ \\
\hline Cooking initial temperature $\left({ }^{\circ} \mathrm{C}\right)$ & $30.0 \pm 0.0$ & $30.3 \pm 0.6$ \\
\hline Cooking final temperature $\left({ }^{\circ} \mathrm{C}\right)$ & $35 \pm 1^{\mathrm{b}}$ & $38 \pm 0^{\mathrm{a}}$ \\
\hline Cooking temperature rate $\left({ }^{\circ} \mathrm{C} / \mathrm{min}\right)$ & $0.23 \pm 0.03^{\mathrm{a}}$ & $0.11 \pm 0.00^{\mathrm{b}}$ \\
\hline Cooking pH & $6.49 \pm 0.01^{\mathrm{a}}$ & $6.45 \pm 0.01^{\mathrm{b}}$ \\
\hline Cooking time (min) & $22 \pm 2^{\mathrm{b}}$ & $68 \pm 3^{\mathrm{a}}$ \\
\hline Cooking speed (rpm) & $9.2 \pm 0.3^{\mathrm{b}}$ & $15.7 \pm 0.3^{\mathrm{a}}$ \\
\hline Cooking revolutions & $200 \pm 20^{\mathrm{b}}$ & $1,063 \pm 32^{\mathrm{a}}$ \\
\hline Total revolutions & $301 \pm 18^{\mathrm{b}}$ & $1,674 \pm 175^{\mathrm{a}}$ \\
\hline Whey draining $\mathrm{pH}$ & $6.50 \pm 0.01^{\mathrm{a}}$ & $6.45 \pm 0.00^{\mathrm{b}}$ \\
\hline Pressing time (min) & $298 \pm 29^{\mathrm{a}}$ & $163 \pm 23^{\mathrm{b}}$ \\
\hline Pressing temperature ${ }^{1}\left({ }^{\circ} \mathrm{C}\right)$ & 20 & 20 \\
\hline Pressing force $^{1}$ (bar) & 2.5 & 2.8 \\
\hline Airing temperature $\left({ }^{\circ} \mathrm{C}\right)$ & 10 & 11 \\
\hline Airing relative humidity ${ }^{1}(\%)$ & 80 & 75 \\
\hline Airing time ${ }^{1}(\mathrm{~d})$ & 4 & 9 \\
\hline Ripening temperature ${ }^{1}\left({ }^{\circ} \mathrm{C}\right)$ & 11 & 10 \\
\hline Ripening relative humidity ${ }^{1}(\%)$ & 85 & 88 \\
\hline
\end{tabular}

${ }_{\mathrm{a}, \mathrm{b}}$ Means with different superscripts in the same row indicate statistically significant differences $(P \leq 0.05)$ between both dairies.

${ }^{1}$ Average data provided by the cheesemakers for the 3 cheese productions.

${ }^{2}$ Data corresponding to the milk-clotting activity of the rennet used for the 3 cheese productions.

${ }^{3}$ Cutting process was calculated as cutting tip speed $\times$ cutting time $\times$ knife density. Knife density refers to the ratio between the number of cutting knives in the cutting frame per its area.

Table 2. Composition, $\mathrm{pH}$, and microstructure traits (mean $\pm \mathrm{SD}$ ) of the raw sheep milk used in the moderate(dairy A) and high-intensity (dairy B) cheesemaking processes $(\mathrm{n}=3)$

\begin{tabular}{lcc}
\hline Item & Dairy A & Dairy B \\
\hline Fat $(\mathrm{g} / 100 \mathrm{~g})$ & $7.2 \pm 0.15$ & $7.2 \pm 0.22$ \\
Fat in DM $(\mathrm{g} / 100 \mathrm{~g})$ & $41.2 \pm 0.7$ & $41.6 \pm 0.8$ \\
Protein $(\mathrm{g} / 100 \mathrm{~g})$ & $5.07 \pm 0.16$ & $4.87 \pm 0.12$ \\
Protein $\mathrm{DM}$ (g/100 g) & $29.0 \pm 0.9$ & $28.0 \pm 0.1$ \\
Casein $(\mathrm{g} / 100 \mathrm{~g})$ & $3.86 \pm 0.04$ & $3.71 \pm 0.09$ \\
Fat-to-casein ratio & $1.86 \pm 0.02$ & $1.95 \pm 0.06$ \\
DM $(\mathrm{g} / 100 \mathrm{~g})$ & $17.47 \pm 0.04$ & $17.41 \pm 0.45$ \\
Lactose $(\mathrm{g} / 100 \mathrm{~g})$ & $4.74 \pm 0.07^{\mathrm{b}}$ & $4.94 \pm 0.09^{\mathrm{a}}$ \\
Calcium $(\mathrm{mg} / \mathrm{kg})$ & $1,494 \pm 18^{\mathrm{a}}$ & $1,436 \pm 10^{\mathrm{b}}$ \\
Magnesium $(\mathrm{mg} / \mathrm{kg})$ & $162 \pm 2^{\mathrm{a}}$ & $155 \pm 0.3^{\mathrm{b}}$ \\
Phosphorus $(\mathrm{mg} / \mathrm{kg})$ & $1,334 \pm 43$ & $1,349 \pm 17$ \\
Milk pH & $6.64 \pm 0.07$ & $6.58 \pm 0.02$ \\
Fat globule sphericity & $0.64 \pm 0.01$ & $0.63 \pm 0.01$ \\
Fat globule diameter ${ }^{1}(\mu \mathrm{m})$ & $5.39 \pm 0.15$ & $5.72 \pm 0.32$ \\
Volume of globular fat $(\%)$ & $64.35 \pm 5.08$ & $57.07 \pm 4.80$ \\
Volume of nonglobular fat $(\%)$ & $1.06 \pm 1.84$ & $0.00 \pm 0.00$ \\
\hline
\end{tabular}

${ }_{\mathrm{a}, \mathrm{b}}$ Means with different superscripts in the same row indicate significant differences $(P \leq 0.05)$ between dairies. ${ }^{1}$ Volume-weighed mean diameter measured by 3 -dimensional image analysis of confocal laser scanning micrographs. 
Cutting was carried out at constant temperature, but with variable time and speed, and then cutting frames were switched for stirrers. During stirring, temperature was raised to between 36 and $38^{\circ} \mathrm{C}$. Curd grains after cooking were pressed in the vat using perforated metal panels, enhancing whey and curd separation. The continuous curd mass was then cut into cubes, introduced in plastic molds with a linen cloth, and pressed in hydraulic horizontal presses until cheese $\mathrm{pH}$ dropped to $\sim 5.5$. After that, cheeses were immersed in a saturated sodium chloride brine solution $(\sim 3.8 \mathrm{M})$ at $10^{\circ} \mathrm{C}$ for 18 $\mathrm{h}$ and ripened for $1 \mathrm{mo}$ in temperature- and humiditycontrolled chambers.

Samples of bulk milk, rennet paste, curd grains after cutting (fresh curd grains; FCG) and cooking (stirred curd grains; SCG), whey generated after cutting (WFCG), whey generated after cooking (WSCG), whey after draining, cheese after pressing, and 1-mo ripened cheese were collected. Milk samples (1 L) were taken from the vat before cheesemaking started, and 2 samples $(0.5 \mathrm{~L}$ each) of whey were collected after the draining process. The FCG and SCG samples together with the whey generated during cutting and cooking processes were collected by submerging a 0.5-L plastic container to a depth approximately halfway between the top and bottom of the vat while stirring. Then, curd grains and whey were separated and weighed in the laboratory for further analysis. For the image analysis of curd-grain features, FCG and SCG samples were obtained by submerging a mesh sieve halfway between the top and bottom of the vat right after the end of cutting and cooking, respectively (Aldalur et al., 2019a). Artisanal rennet paste ( $\sim 50 \mathrm{~g})$ was collected from each dairy, stored in plastic containers, and kept in refrigeration $\left(4^{\circ} \mathrm{C}\right)$ until analysis. Two whole cheeses after pressing (immediately before being brined) and 2 brined cheeses after 1 mo of ripening were collected, and each cheese was cut into 6 similar wedges. For CLSM analysis, FCG and SCG samples were immersed in a formaldehyde solution at $0.5 \%(\mathrm{wt} / \mathrm{vol})$ to prevent structure changes until analysis, while milk, pressed cheese, and 1 -mo ripened cheese were kept in refrigeration $\left(4^{\circ} \mathrm{C}\right)$. The CLSM analyses for all of the samples were carried out within $24 \mathrm{~h}$. For the analysis of gel-compression work at cutting point, milk was kept in refrigeration for no longer than $5 \mathrm{~h}$ until analysis. For cheese texture analysis, 1 wedge of each 1-mo ripened cheese was kept in refrigeration $\left(4^{\circ} \mathrm{C}\right)$ for $3 \mathrm{~d}$ until analysis. For other analyses, samples were frozen at $-80^{\circ} \mathrm{C}$ until analysis.

\section{Physicochemical Analysis}

Milk, drained whey, WFCG, WSCG, pressed cheese, and 1-mo ripened cheese were analyzed using a near infrared spectrometer (SpetrAlyzer 2.0, ZEUTEC GmbH, Rendsburg, Germany). This method was used to analyze fat, protein, DM in all the samples except curd grains, and lactose content in milk samples. Milk casein was determined by separating the nitrogen fractions by acidification and analyzing with the Kjeldahl method (ISO/IDF, 2004a). The FCG and SCG were analyzed for fat, protein, and DM using Van Gulik (ISO/IDF, 2008a), Kjeldahl (ISO/IDF, 2008b), and oven-drying (ISO/IDF, 2004b) methods, respectively. Mineral content of milk, whey, and pressed cheese were determined by microwave digestion followed by flame atomic absorption spectroscopy for calcium and magnesium (de la Fuente et al., 1997), and a photometric method for phosphorus (AOAC International, 2005). All physicochemical analyses were done in duplicate.

\section{Rennet Milk-Clotting Activity and Gel-Compression Work at Cutting Point}

Rennet pastes were prepared in an artisan way by each cheesemaker, and the coagulating activity was not standardized. The cheesemaker experimentally decided the amount of rennet to be added to the vat, and milk-clotting activity of the artisan rennet pastes was determined in duplicate as previously described by Bustamante et al. (2000). The method is based on the visual determination of the appearance of the first floccules produced by the addition of a known amount of clotting enzyme in a known amount of standardized milk at constant conditions. Briefly, reconstituted skim milk at $12 \%$ (Chr Hansen, Hoersholm, Denmark) was poured into test tubes, and an adequate dilution of the rennet extract was added. Test tubes were placed in a rotating device at an angle of $30^{\circ}$ and a constant temperature of $30^{\circ} \mathrm{C}$. The time from the addition of rennet to the appearance of the first floccules was measured and results were expressed as rennet units per gram of rennet paste.

Because coagulation conditions affect the rheological properties of the curd and the cheese yield (Ikonen et al., 1999; Lucey, 2011), the coagulation process was studied to establish whether the starting point (curd before cutting) was similar between the 2 dairies. For the measurement of gel-compression work at cutting point, milk coagulation conditions $(\mathrm{pH}$, temperature, rennet concentration, and time until curd cutting point) used during the cheese manufacturing were simulated in the laboratory using the raw milk and rennet paste collected in the small dairies on the same day. A compression-extrusion test was carried out using a texture analyzer (TA-XT2i; Stable Micro Systems, Godalming, UK) armed with a $5-\mathrm{kg}$ load cell and a 25-mm diameter cylindrical probe (Nájera et al., 2009). 
Milk and rennet were poured into a plastic container (28-mm diameter), and after clotting simulated the real conditions, the test was carried out using a test speed of $2 \mathrm{~mm} / \mathrm{s}$ and a penetration length of $10 \mathrm{~mm}$. Gelcompression work was defined as the area of the curve $(\mathrm{g} \times \mathrm{s})$ measured during penetration. Eight samples were analyzed for each simulated production condition, and the mean value was used.

\section{Curd-Grain Properties}

Curd-grain size, shape, and particle size distribution (PSD) properties were measured by 2-dimensional image analysis using ImageJ software (National Institutes of Health, Bethesda, MD) as previously described by Aldalur et al. (2019a). The values for area, perimeter, maximum Feret diameter, elongation, rectangularity, and circularity were measured for FCG and SCG. Likewise, PSD traits were calculated based on the percentile dimensions of the area of the curd grains after cutting and cooking. The PSD traits described the degree of homogeneity of the curd particle sizes and the following indexes were used: uniformity index and coefficient, size range variation, relative span, and graphic skewness and kurtosis (Aldalur et al. 2019a).

\section{Cheese Yield, Milk Component Recovery, and Texture}

The actual cheese yield ( $\mathrm{kg}$ of cheese/100 kg of milk) was calculated as the ratio between the weight of fresh cheese after pressing, or after 1 mo of ripening, and the amount of raw milk used in the processing. Milk volume was measured using flowmeters with mean precision values of $\pm 0.15 \%$ and converted into weight by multiplying by its density. Cheeses were weighed using commercial weighing scales with mean precision value of \pm 1 g. Composition-adjusted cheese yield ( $\left.Y_{C A}\right)$ was measured to assess the effect of the technological conditions on cheese yield as follows:

$$
Y_{C A}=Y_{A} \times \frac{\left(F_{R}+P_{R}\right)}{F_{C}+P_{C}} \times \frac{100-M_{A}}{100-M_{R}}
$$

where $F_{R}$ and $P_{R}$ were the reference values for fat $(7.2 \%)$ and protein $(5.0 \%)$ in milk, $F_{C}$ and $P_{C}$ were the actual fat and protein contents of milk, and $M_{A}$ and $M_{R}$ were the actual and reference ( $42 \%$ for cheese after pressing and $38.7 \%$ for 1 -mo ripened cheese) moisture contents of cheese, respectively. The cheese yield efficiency was calculated as the percentage of the ratio between $Y_{C A}$ and the Van Slyke's theoretical cheese yield (Barbano and Sherbon, 1984). The percentage of fat, protein, cal- cium, magnesium, and phosphorus recoveries to cheese were calculated as the total amount of the compound recovered to the cheese on a milk basis (Guinee et al., 2006).

Cheese texture analysis was carried out in 1-mo ripened cheese samples using a single uniaxial compression test at 50\%. A texture analyzer (TA-XT2i; Stable Micro Systems) equipped with a 25-kg cell and 25-mm diameter cylindrical probe at a constant speed of 1 $\mathrm{mm} / \mathrm{s}$ was used for the analysis. Cheese samples were tempered $\left(\sim 25^{\circ} \mathrm{C}\right)$ for $1 \mathrm{~h}$ and cut into cubes of 1.2 $\mathrm{cm}$ in each side, casting aside $\sim 1 \mathrm{~cm}$ from the rind of the cheese. Ten cheese cubes were analyzed per cheese wedge, and 2 different cheeses were tested for each cheese manufacturing. The textural traits measured are explained in Figure 1.

\section{Whey Losses and Chemical Oxygen Demand}

The fat, protein, casein, calcium, magnesium, and phosphorus loss in the whey after cutting, cooking, and draining were measured (on a milk basis) as the percentage of the ratio between the total amount of the compound in whey and the initial total amount in milk (Guinee et al., 2006). The total amount of whey in the intermediate samples was estimated as the total milk weight multiplied by the whey yield, calculated as the ratio between the weight of whey and the weight of curd and whey after cutting and cooking (Everard et al., 2008).

The content of casein fines in WFCG, WSCG, and drained whey samples was measured in duplicate using the method described by Everard et al. (2008). Briefly, the whey sample was centrifuged for 15 min at $1,500 \times$ $g$. Fat was then removed, and supernatant liquid was poured without disturbing the pellet. Distilled water was added to the tube, and the centrifugation and cleaning process was repeated. Finally, distilled water at $40^{\circ} \mathrm{C}$ was added before the whole content of the tube was filtered onto a previously oven-dried filter paper with a Buckner funnel under vacuum conditions. The filter paper was then dried in an oven at $102^{\circ} \mathrm{C}$ for 1 $\mathrm{h}$ and weighed. Results were expressed as milligram of casein fines per kilogram of whey.

The chemical oxygen demand (COD) of whey was only determined for drained whey samples by the dichromate method in small-scale sealed-tubes (ISO, 2002). An adequate dilution of the whey samples was introduced in the sealed-tubes (HI94754C-25, Hannah Instruments Inc., Woonsocket, RI), mixed, and digested at $150^{\circ} \mathrm{C}$ for $2 \mathrm{~h}$. Absorbance was measured using a spectrophotometer (Spectronic 20D, Milton Roy, France), and results were compared against a standard 


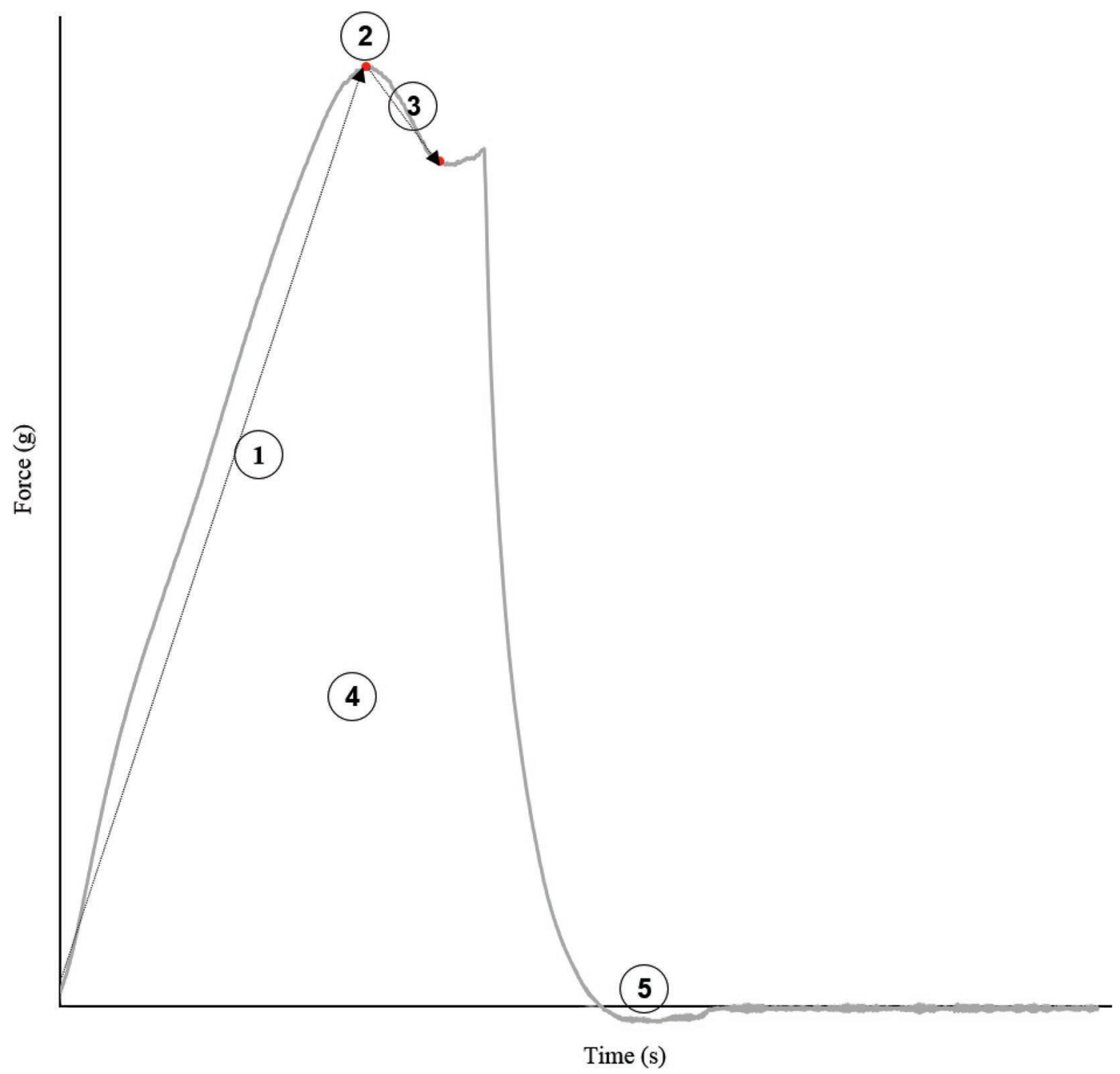

Figure 1. Standard curve obtained in the single uniaxial compression analysis using a texture analyzer and the variables measured for each texture feature. (1) Stiffness is the resistance to reversible deformation, proportional to the force applied. Slope between the start and the maximum force is the stiffness measure $(\mathrm{g} / \mathrm{s})$. (2) Hardness and fracturability are the maximum force of compression and the stress required to fracture the sample, respectively. In this case, both measurements are at the same point of the curve (g). (3) Brittleness is considered the structural collapse period, where internal eyes and small cracks disappear. It was calculated as the slope between the maximum force and the next lower point $(\mathrm{g} / \mathrm{s})$. (4) Hardness work is indicative of the resistance to deformation over time; it was measured as the total area under the compression curve $(\mathrm{g} \cdot \mathrm{s})$. (5) Adhesiveness is the work necessary to overcome the attractive forces between the surface of the sample and the test probe. The adhesiveness measure is the area in the negative zone after the decompression of the sample $(\mathrm{g} \cdot \mathrm{s})$.

solution of potassium hydrogen phthalate. Samples were measured in duplicate and results expressed as milligrams of oxygen per liter of whey.

\section{Confocal Laser Scanning Microscopy and Image Analysis}

An inverted confocal microscopy (SP2; Leica Microsystems, Heidelberg, Germany) was used for CLSM to analyze the microstructure of milk, FCG, SCG, cheese after pressing, and cheese after 1 mo of ripening, as previously reported (Ong et al., 2011). Briefly, FCG and SCG samples were immersed in a phosphate-buffered saline solution $(\mathrm{pH} 7.4)$ for at least $1 \mathrm{~h}$ to rinse the formaldehyde solution. Solid samples were cut into approximately $5 \times 5 \times 2 \mathrm{~mm}$ and stained at $\sim 4^{\circ} \mathrm{C}$ using fast green FCF $(0.1 \mathrm{mg} / \mathrm{mL})$ and nile red $(0.1 \mathrm{mg} /$ $\mathrm{mL}$; both from Sigma-Aldrich, Steinheim, Germany). For milk samples, fast green FCF $(0.02 \mathrm{mg} / \mathrm{mL})$, nile red $(0.02 \mathrm{mg} / \mathrm{mL})$, agarose $(0.5 \%$; Sigma-Aldrich), and milk were mixed and placed in the imaging dish (0.17mm thick). Excitation wavelengths of 638 and $488 \mathrm{~nm}$ were used for protein and fat, respectively.

Three-dimensional (3D) image analysis was performed for the CLSM micrographs using ImageJ software (National Institutes of Health) as previously 
reported by Aldalur et al. (2019b). Briefly, a minimum of 20 adjacent micrographs were used for the reconstruction of 3D images with an observation depth of a minimum of $10 \mu \mathrm{m}$. The quality of the 3D images was improved, thresholded, and quantified by 3D-object counter analysis. Fat volume, fat globule or fat droplet diameter, sphericity, and protein-network porosity were determined. As previously described by Aldalur et al. (2019b), 2 fat globule populations were defined: globular fat droplets (fat globule diameter $<6 \mu \mathrm{m}$ ) and nonglobular or coalesced fat droplets (droplet diameter $>10 \mu \mathrm{m}$ ). The percentage of fat volume contributed by globular or nonglobular fat was quantified.

\section{Statistical Analysis}

The IBM-SPSS version 25.0 (IBM Corp., Armonk, NY) and XLSTAT (Addinsoft, Paris, France) software were used for statistical analysis. The Student's $t$-test was used to separately assess the effect of cutting and cooking conditions ( $l=2$; moderate or high intensity) and curd syneresis ( $l=2$; after cutting or cooking) on the composition and properties of curd grains, whey, and cheese. Partial least square regression (PLSR) analyses were used to investigate relationships between the raw milk properties together with the technological settings used during cheesemaking, and the curd, whey and cheese properties, and cheese yield and whey losses obtained in the small dairies. This multivariate statistical approach is designed to handle the case of a large number of correlated independent variables, as in the present study. The PLSR analyses were performed using 2 different variable matrices ( $X$ and $Y$ variables) to investigate correlations between them. Two-dimensional plots formed by the model components (latent dimensions $\mathrm{t} 1$ and $\mathrm{t} 2$ ) with greater variance explained for $X$ and $Y$ variables were used to show the relationships between variables. Additionally, the experimental units (cheese productions) were located in the plots. The PLSR analyses were carried out on self-scaling variables, and only those variables showing scores for variable importance in the projection higher than 0.8 and loadings higher than 0.5 in the latent dimensions were included. Statistical significance was declared at $P \leq 0.05$.

\section{RESULTS AND DISCUSSION}

\section{Coagulation and Cutting Process}

It is well known that milk coagulation is dependent on variables such as temperature, $\mathrm{pH}$, calcium, and rennet concentration (Jacob et al., 2011; Horne and Lucey,
2017). In the present study, the coagulation process in dairy B was carried out at a temperature approximately $2^{\circ} \mathrm{C}$ higher, and with a coagulating activity of almost double with respect to dairy A (18.0 vs. 9.5 rennet unit/100 L of milk). As expected, this resulted in a shorter clotting time used in dairy B, but could also affect the gel-network properties with a gel-compression work higher than in dairy A (Table 1). Other authors have also reported changes affected by those variables in coagulum firmness, curd firmness, and gel-firming rate as well as in the subsequent texture of the cheese (Nájera et al., 2003; Jacob et al., 2011).

Figure 2 shows the relationships obtained by PLSR analysis between technical, compositional, and microstructural variables involved before and after the cutting process during the cheesemaking trials in the small dairies. In this context, higher cutting speed and time generated higher $(P \leq 0.05)$ fat loss in the whey after the cutting process (Table 3 ). The loss of casein fines also showed an increasing trend when cutting intensity increased, although not statistically significant differences were observed due to the high intravariability among the cheese productions of dairy B. This probably happened due to the changes in the gel-compression work values at cutting point, which appeared positively correlated with casein fines loss in the PLSR graph (Figure 2). Therefore, these results suggested that the combined effect of gel-compression work and cutting settings greatly affected the loss of casein fines after cutting. This agrees with other studies that reported that the gel should not harden excessively to avoid casein and fat losses when manufacturing semihard cheeses (Kammerlehner, 2009; Lucey, 2011). The gelcompression work was also positively correlated with the lactose content of milk (Figure 2), and even though the mechanism is unclear, other authors have also reported higher curd firmness when lactose content in milk was higher (Bland et al., 2015). Losses of mineral compounds in the whey after cutting were especially correlated with the initial amount of each mineral in milk. This is because part of the calcium, magnesium, and phosphorus is not associated with caseins, and these salts are highly water-soluble compounds (Figure 2).

Regarding curd-grain size and shape, a higher cutting intensity generated significantly $(P \leq 0.05)$ smaller, more circular, and less elongated particles at the end of this process (Figure 2; Table 3). Additionally, the size distribution of FCG was highly heterogeneous, regardless of the cutting intensity used, as shown by the relative span value (Table 3 ) and other PSD traits (Table 4). Other studies have also reported high PSD heterogeneity for curd grains and have suggested that 


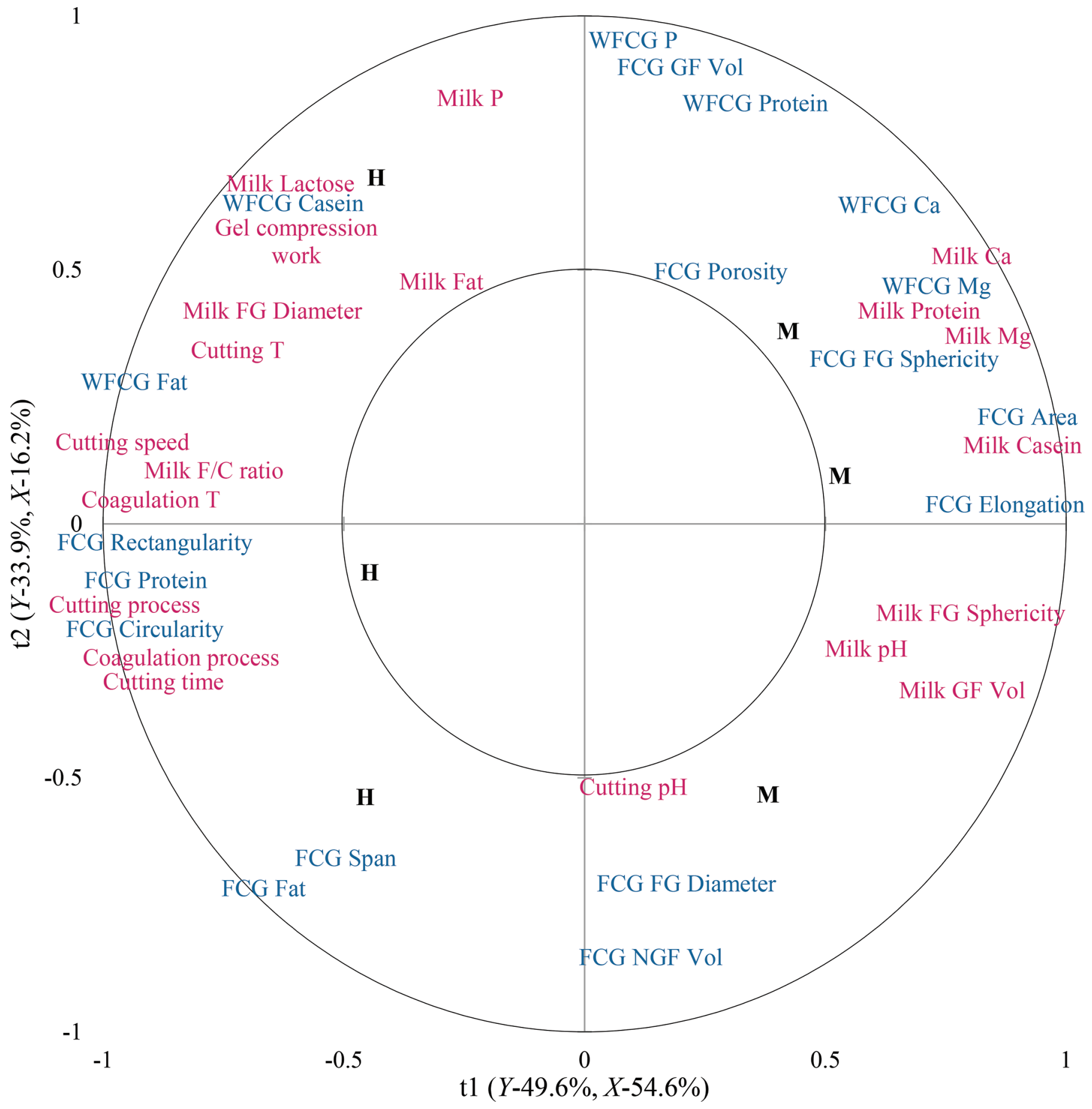

Figure 2. Partial least squares regression plot showing the relationships between technological settings of coagulation and cutting, together with the composition and microstructure of milk ( $X$-variables, in magenta), and the composition, microstructure, size, shape, and distribution traits of curd grains after the cutting process (FCG; $Y$ variables, in blue). Each cheese manufacturing is boldfaced and labeled as M (moderateintensity processing; dairy A) or $\mathrm{H}$ (high-intensity processing; dairy B). The inner circle indicates the correlation value $|0.5|$. The outer circle indicates the maximum correlation value $|1| \mathrm{WFCG}=$ whey after the cutting process; $\mathrm{FG}=$ fat globule; FD = fat droplet; GF $=$ globular fat; $\mathrm{NGF}=$ nonglobular fat; $\mathrm{Vol}=$ volume $\mathrm{F} / \mathrm{C}=$ fat-to-casein ratio; $\mathrm{Span}=$ relative span; $\mathrm{T}=$ temperature; $\mathrm{t} 1=$ latent dimension $1 ; \mathrm{t} 2=$ latent dimension 2. Cutting process was calculated as cutting speed $\times$ cutting time $\times$ knife density; coagulation process was calculated as coagulation time $\times$ rennet activity $\times$ rennet concentration. 
Table 3. Values (mean $\pm \mathrm{SD}$ ) of composition, microstructure, size, shape, and distribution traits of curd grains, and whey losses, after cutting and cooking for the moderate- (dairy A) and high-intensity (dairy B) processes during Idiazabal PDO cheese productions (n = 3) in small dairies; significance values of the curd syneresis factor for both dairies are also provided

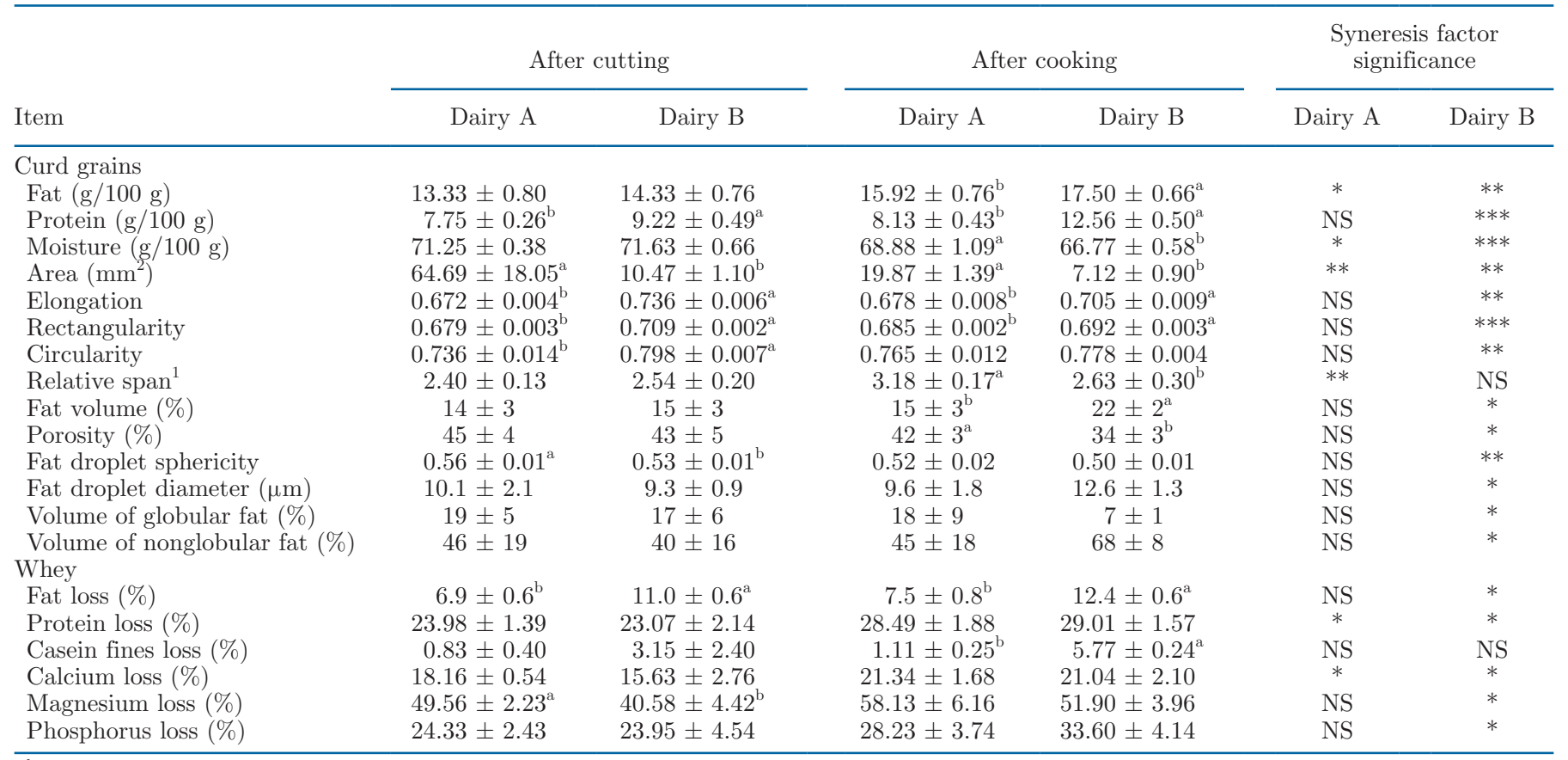

${ }_{\mathrm{a}, \mathrm{b}}$ Means with different superscripts in the same row and process step (cutting or cooking) indicate statistically significant differences $(P \leq 0.05)$ between dairies.

${ }^{1}$ Relative span $=\left(D_{90}-D_{10}\right) / D_{50}$, where $D_{x}$ is the xth percentile dimension of the curd grain area distribution for each cheese production. Values closer to 1 indicate more homogeneous particle size distribution.

$* P \leq 0.05 ;{ }^{* *} P \leq 0.01 ; * * * P \leq 0.001 ; \mathrm{NS}=P>0.05$

the cutting process was the main cheesemaking process to influence particle distribution (Iezzi et al., 2012; Aldalur et al., 2019a).

Microstructure traits of FCG did not show remarkable differences between moderate- and high-intensity cutting processes (Table 3; Figure 3A and E). However, FCG microstructure traits were correlated in the latent dimension t2 ( $Y$-axis) with some milk components, whey compound losses, and cutting $\mathrm{pH}$, which might confirm the importance of milk composition and acidity on the formation of curd structure and the losses of water-soluble compounds in the whey (Ong et al., 2011, 2013).

\section{Cooking Process}

During cooking, curd grains released fat, protein, casein, calcium, magnesium, and phosphorus to the whey,

Table 4. Size and distribution traits (mean $\pm \mathrm{SD}$ ) of curd grains after cutting (FCG) and cooking (SCG) for the moderate- (dairy A) and high-intensity (dairy B) processes during Idiazabal PDO cheese production $(\mathrm{n}=$ 3) in small dairies

\begin{tabular}{|c|c|c|c|c|}
\hline \multirow[b]{2}{*}{ Item } & \multicolumn{2}{|c|}{ FCG } & \multicolumn{2}{|c|}{ SCG } \\
\hline & Dairy A & Dairy B & Dairy A & Dairy B \\
\hline Perimeter & $30.59 \pm 4.84^{\mathrm{a}}$ & $11.88 \pm 0.76^{\mathrm{b}}$ & $16.25 \pm 0.76^{\mathrm{a}}$ & $9.98 \pm 0.71^{\mathrm{b}}$ \\
\hline Maximum Feret diameter & $10.80 \pm 1.63^{\mathrm{a}}$ & $4.13 \pm 0.26^{\mathrm{b}}$ & $5.82 \pm 0.24^{\mathrm{a}}$ & $3.53 \pm 0.23^{\mathrm{b}}$ \\
\hline Uniformity index & $7.91 \pm 1.03^{\mathrm{a}}$ & $6.72 \pm 0.36^{\mathrm{b}}$ & $4.96 \pm 1.02^{\mathrm{b}}$ & $9.20 \pm 1.01^{\mathrm{a}}$ \\
\hline Size range variation & $99.99 \pm 22.50$ & $97.94 \pm 5.98$ & $115.23 \pm 10.41$ & $101.69 \pm 12.43$ \\
\hline Coefficient of uniformity & $3.72 \pm 0.23^{\mathrm{b}}$ & $4.71 \pm 0.41^{\mathrm{b}}$ & $5.37 \pm 0.66^{\mathrm{a}}$ & $3.87 \pm 0.51^{\mathrm{b}}$ \\
\hline Graphic skewness & $0.48 \pm 0.01$ & $0.44 \pm 0.08$ & $0.53 \pm 0.06$ & $0.50 \pm 0.04$ \\
\hline Graphic kurtosis & $1.34 \pm 0.38$ & $1.11 \pm 0.16$ & $1.27 \pm 0.05^{\mathrm{a}}$ & $1.07 \pm 0.06^{\mathrm{b}}$ \\
\hline
\end{tabular}

$\overline{\mathrm{a}, \mathrm{b}}$ Means with different superscripts in the same row and type of sample indicate statistically significant differences $(P \leq 0.05)$ between dairies. 
increasing the mean values for all the compound losses on a milk basis (Table 3 ). However, significant increases $(P \leq 0.05)$ were only measured for protein and calcium losses when both moderate- and high-intensity cooking procedures were applied, and for fat, magnesium, and phosphorus losses when the high-intensity cooking was applied. Curd-grain composition also changed during cooking mainly due to the reduction in moisture content. This was particularly remarkable in dairy B where a higher cooking speed, time, and temperature as well as a lower $\mathrm{pH}$ were measured; therefore, syneresis was especially enhanced (Table 3). Additionally, curd-grain size shrunk $(P \leq 0.05)$ despite the cooking intensity used, with a higher overall size reduction for the moderate-intensity cooking (3.3 vs. 1.5 times) due to the bigger initial FCG size and the physical difficulty of the smaller FCG to further reduce in size (Iezzi et al., 2012). Regarding the shape of the curd grains, these especially changed $(P \leq 0.05)$ when a high-intensity cooking process was used, presumably due to the increased probability of collision between particles, or particles and equipment (van den Bijgaart, 1988). Contrarily, PSD did not significantly $(P>0.05)$ change when high-intensity cooking was applied, but the relative span value increased $(P \leq 0.05)$ for the moderate-intensity cooking, indicating that the PSD heterogeneity increased (Table 3 ). This probably occurred due to the presence of a small amount of large SCG together with the general reduction of curd-grain size, which affected PSD traits (Table 4), as previously reported (Aldalur et al., 2019a).

The microstructure of the curd grains significantly $(P$ $\leq 0.05$ ) changed during cooking but, only when high cooking intensity was used. The porosity of the protein network significantly $(P \leq 0.05)$ decreased (Table 3; Figure $3 \mathrm{E}$ and $\mathrm{F}$ ) due to the increased syneresis (reduced SCG moisture) induced by the long time, high speed, temperature raise $\left(38^{\circ} \mathrm{C}\right)$, and consequent $\mathrm{pH}$ drop during cooking (Figure 4), as observed by other authors (Ong et al., 2011; Aldalur et al., 2019b). The size, shape, and distribution of the fat droplets also changed $(P \leq 0.05)$ during cooking, decreasing the sphericity and the volume of globular fat, and increasing the nonglobular or coalesced fat volume (Table 3; Figure $3 \mathrm{~F}$, white arrows). The observation of microstructural changes in curd grains of the high-intensity cooking process (Figure $3 \mathrm{E}$ and $\mathrm{F}$ ) and the lack of differences in the moderate process (Figure $3 \mathrm{~A}$ and $\mathrm{B}$ ) could also be related to the size of the curd grains. Small curd grains shrink more and faster than the large ones due to Darcy's law (Fagan et al., 2017). Therefore, the curd grains after cooking in dairy B (Figure 3B)
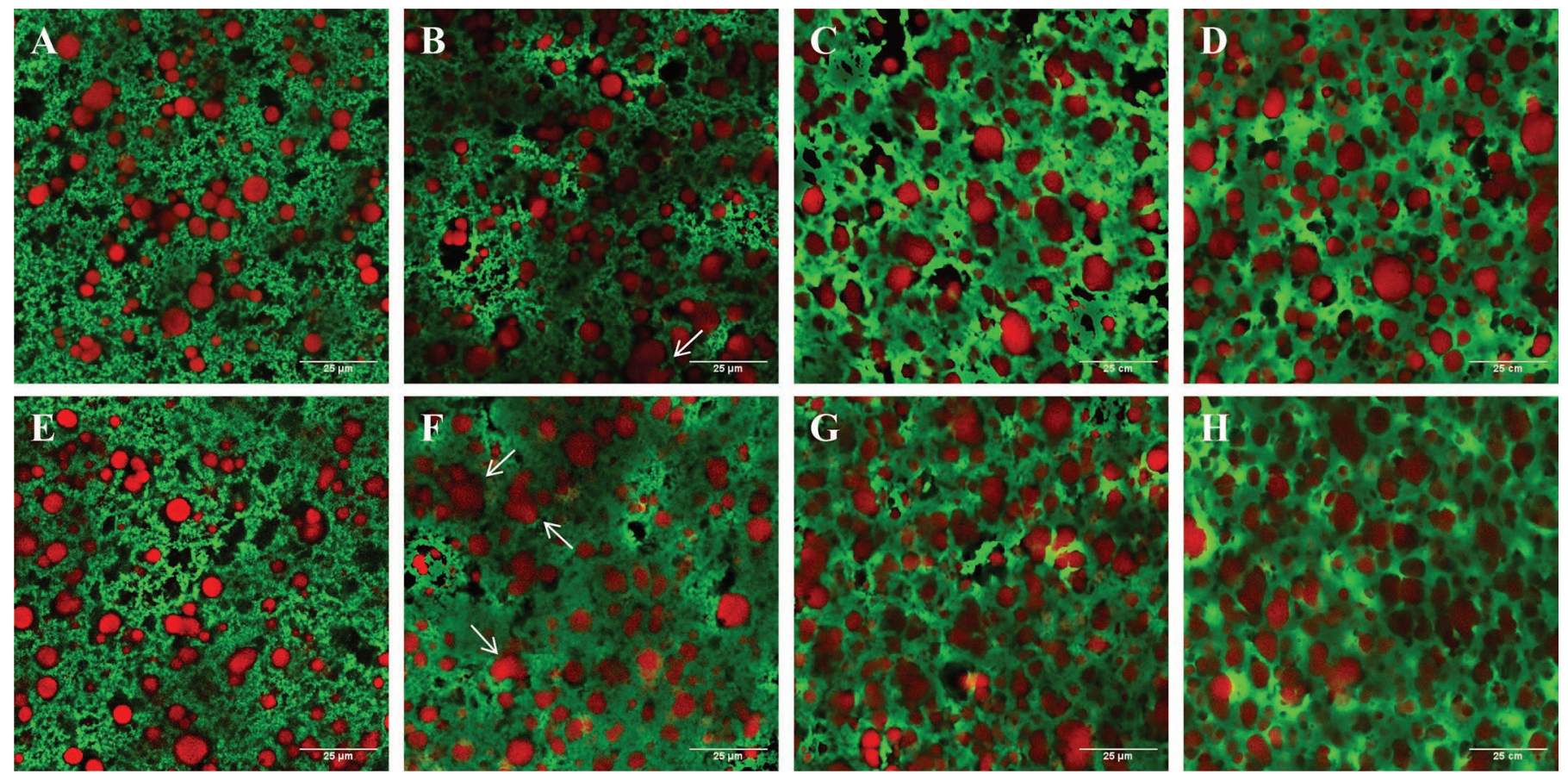

Figure 3. Confocal laser scanning microscopy images of curd grains after cutting (A, E), curd grains after cooking (B, F), cheese after pressing $(\mathrm{C}, \mathrm{G})$, and cheese after 1 mo of ripening $(\mathrm{D}, \mathrm{H})$ for moderate- (dairy A, A-D) and high-intensity (dairy B, E-H) cutting and cooking processes. Images were obtained using a $63 \times$ objective lens and digitally magnified $2 \times$. The scale bars are $25 \mu \mathrm{m}$ in length. Fat appears in red, and protein appears in green. White arrows indicate coalesced fat globules. 


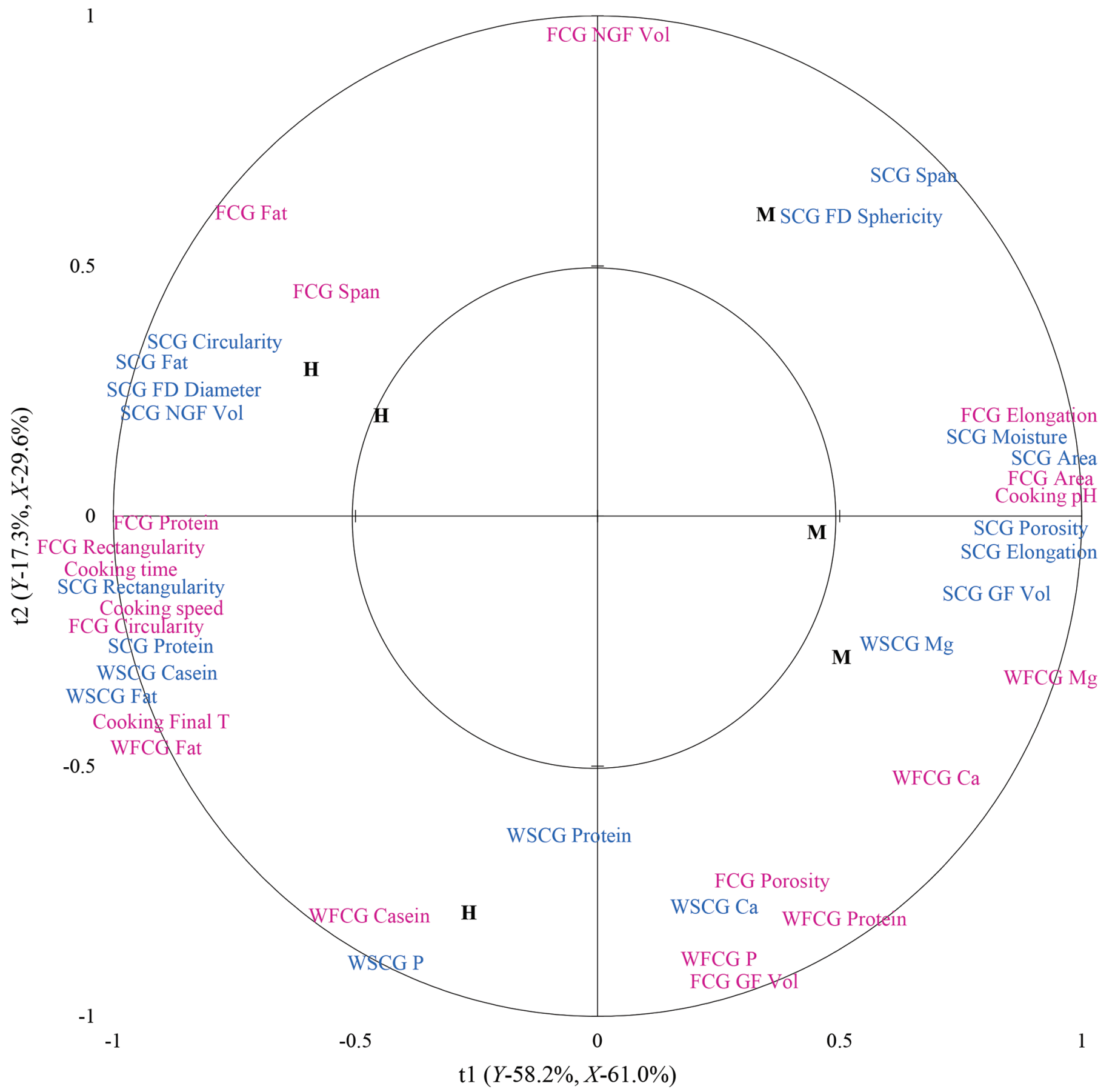

Figure 4. Partial least squares regression plot showing the relationships between the technological settings of cooking together with the composition, microstructure, size, shape, and distribution traits of curd grains after cutting (FCG; $X$-variables, in magenta), and the composition, microstructure, size, shape, and distribution traits of curd grains after the cooking process (SCG; $Y$ variables, in blue). Each cheese manufacturing is boldfaced and labeled as M (moderate-intensity processing; dairy A) or $\mathrm{H}$ (high-intensity processing; dairy B). The inner circle indicates the correlation value $|0.5|$. The outer circle indicates the maximum correlation value $|1|$. WFCG $=$ whey after the cutting process; WSCG $=$ whey after cooking process; FG = fat globule; FD = fat droplet; $\mathrm{GF}=$ globular fat; $\mathrm{NGF}=$ nonglobular fat; Vol = volume; Span = relative span; $\mathrm{T}=$ temperature; $\mathrm{t} 1=$ latent dimension $1 ; \mathrm{t} 2=$ latent dimension 2. 
showed a less porous protein matrix, which could indicate a higher shrinkage of the curd grain.

\section{Combined Effect of Cutting and Cooking Processes}

The composition and properties of the curd grains and whey generated after cooking is the result of the combination of both cutting and cooking processes. Therefore, Figure 4 plots the relationships obtained by PLSR analysis between the compositional, microstructural, physical, and technical variables for both processes. After the cooking process, statistically higher $(P \leq 0.05)$ fat and casein losses in whey were measured for dairy B (Table 3), regardless of the size of the curd grain at the start of the cooking (FCG). In this case, bigger FCG cooked with a moderate-intensity cooking process resulted in lower fat and casein losses than smaller FCG cooked with a high-intensity procedure. This suggested that the shattering of curd grains, and consequent fat and casein losses in whey during cooking, was especially enhanced by the cooking intensity used and, to a lesser extent, by the FCG size at the start of the cooking process (Figure 4). It is worth noting that during the elaboration of Idiazabal cheese, no healing step is carried out between the cutting and cooking processes. Previous studies have shown that this step could have beneficial effects in the retention of fat and moisture, and consequently increase cheese yield (Riddell-Lawrence and Hicks, 1988). The development of a skin in the outside layer of the curd grains is essential to reduce fat and casein losses in the whey. Therefore, including a healing period or reducing the stirring intensity at the start of the cooking process to just enough to avoid curd grains to deposit in the bottom of the vat, could potentially improve the component losses in the whey, as previously suggested (Johnston et al., 1998; Aldalur et al., 2019a).

At the end of the cooking process, SCG were smaller, more rectangular, less elongated, and showed more homogeneous PSD when high-intensity cutting and cooking processes were used. The difference in the physical and compositional properties of the curd grain could affect the deformation capacity of curd grains and the subsequent compaction of the curd at pressing (Fagan et al., 2017). The deformation capacity of curd grains means the capacity of the curd grains to adapt their shape when a pressure is exerted. If the deformation capacity is good, the ability of the curd grains to create a continuous curd mass will be improved, and their fusion with other curd grains during pressing and ripening enhanced. Regarding SCG microstructure, high and moderate cutting and cooking processes led to microstructurally different $(P \leq 0.05)$ curds (Figure 3B and $\mathrm{F}$ ), particularly remarkable for porosity and total fat volume (Table 3). Additionally, Figure 4 showed high correlations $(P \leq 0.05)$ between the technical settings used during cooking and the microstructural properties of SCG, unlike for the cutting process (Figure 2). The high-intensity cooking process increased the nonglobular fat volume and mean diameter of the droplets, while it decreased the amount of globular fat, porosity of the protein network, and the sphericity of the fat droplets. Therefore, the microstructure of curd grains was mostly affected by the cooking process, although the result of the technical settings used during cutting (i.e., the curd-grain size) could remarkably affect the SCG microstructure at the end of cooking, as mentioned before.

\section{Cheese Properties, Yield, and Whey Losses}

Figure 5 shows the results of the PLSR analysis on the relationships between milk properties and cheesemaking technical settings, and the properties of the cheeses after pressing and ripened for $1 \mathrm{mo}$ and the composition of drained whey. Generally, all variables correlated with the cheesemaking technical settings were located along the latent dimension t1 ( $X$-axis). High cutting and cooking intensities were negatively correlated with the actual and composition-adjusted cheese yield, although only significant $(P \leq 0.05)$ differences were observed for the actual yield for 1-mo ripened cheeses (Table 5). Both actual and compositionadjusted yields were positively correlated with cheese moisture and compound recoveries in the multivariate approach, particularly protein and calcium recoveries to both $Y_{C A}$, and fat and phosphorus to $Y_{A}$ (Figure 5). Protein, calcium, and phosphorus are the main agents responsible for forming the protein network, while fat fills the pores of that structure (Everett and Auty, 2017). Therefore, a higher recovery of these compounds would turn into increased yield values as shown in the multivariate approach. On the contrary, higher cutting and cooking intensities led to increased milk component losses and COD in the whey. The COD of the drained whey did not significantly differ $(P>0.05)$ between intensity processes due to the high intraprocess variability in the cheesemaking trials, but mean values were rather different (77.2 vs. $96.2 \mathrm{~g} / \mathrm{L}$ for moderate and high intensities, respectively). However, the casein fines losses measured in the drained whey did not differ $(P>$ 0.05 ) between dairy A and B (Table 5) because a filter was used to recover casein fines after the high-intensity process, causing a significant reduction when compared with the whey generated after cooking (Table 3). Therefore, casein fines were recovered in the curd mass. However, this could close the pores and impair further expulsion of the whey during the compaction of the curd grains in the vat and during pressing, causing an 


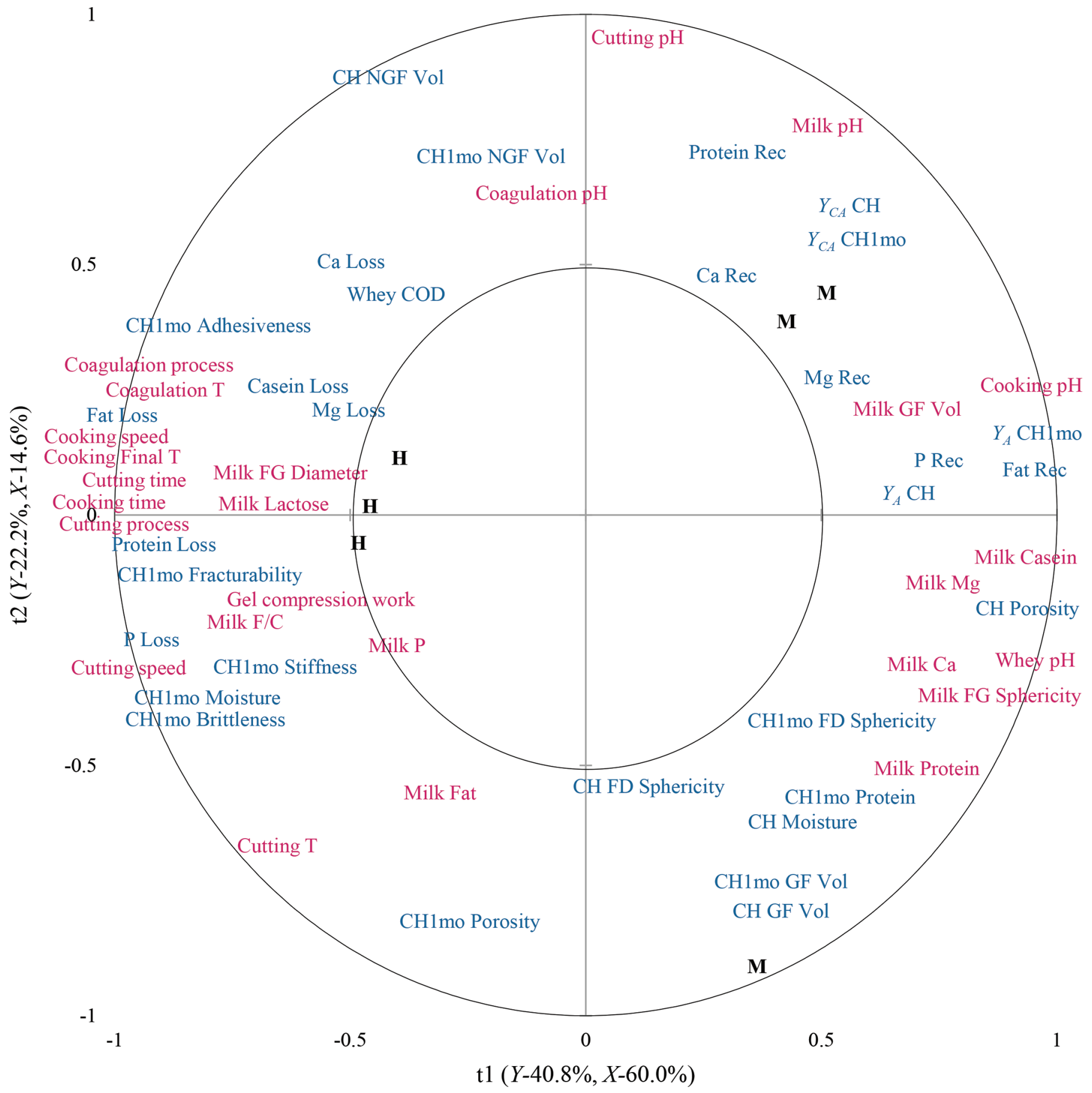

Figure 5. Partial least squares regression plot showing the relationships between the technological settings using during cheesemaking together with the composition and microstructure of milk ( $X$-variables, in magenta) and the composition, microstructure, and texture of pressed cheese $(\mathrm{CH})$ and 1-mo ripened cheese $(\mathrm{CH} 1 \mathrm{mo})$ samples, and losses and chemical oxygen demand (COD) in whey after draining ( $Y$ variables, in blue). Each cheese manufacturing is boldfaced and labeled as M (moderate-intensity processing; dairy A) or H (high-intensity processing; dairy B). The inner circle indicates the correlation value $|0.5|$. The outer circle indicates the maximum correlation value $|1|$. FG $=$ fat globule; FD $=$ fat droplet; $\mathrm{GF}=$ globular fat; $\mathrm{NGF}=$ nonglobular fat; $\mathrm{Vol}=$ volume; $\mathrm{F} / \mathrm{C}=$ fat-to-casein ratio; Span $=$ relative span; $Y_{A}=$ actual yield; $Y_{C A}=$ composition-adjusted cheese yield; Rec = Recovery; $\mathrm{t} 1=$ latent dimension $1 ; \mathrm{t} 2=$ latent dimension 2 . Cutting process was calculated as cutting speed $\times$ cutting time $\times$ knife density; coagulation process was calculated as coagulation time $\times$ rennet activity $\times$ rennet concentration. 
Table 5. Values (mean $\pm \mathrm{SD}$ ) of cheese yield, milk component losses in whey, and milk component recoveries in cheese for the moderate- (dairy A) and high-intensity (dairy B) cutting and cooking processes during Idiazabal PDO cheese production $(\mathrm{n}=3)$ in small dairies

\begin{tabular}{lcc}
\hline Item & Dairy A & Dairy B \\
\hline Milk component loss in whey (\%) & & \\
Fat & $8.5 \pm 0.7^{\mathrm{b}}$ & $13.1 \pm 0.8^{\mathrm{a}}$ \\
Protein & $30.47 \pm 0.52^{\mathrm{b}}$ & $31.82 \pm 0.44^{\mathrm{a}}$ \\
Casein fines & $0.68 \pm 0.43$ & $1.60 \pm 0.88$ \\
Calcium & $25.41 \pm 1.07$ & $26.12 \pm 1.17$ \\
Magnesium & $57.74 \pm 1.20$ & $58.54 \pm 1.39$ \\
Phosphorus & $26.25 \pm 2.09^{\mathrm{b}}$ & $31.68 \pm 1.44^{\mathrm{a}}$ \\
Milk component recovery in cheese (\%) & & \\
Fat & $91.58 \pm 0.63^{\mathrm{a}}$ & $86.95 \pm 0.70^{\mathrm{b}}$ \\
Protein & $78.39 \pm 2.48$ & $78.86 \pm 1.70$ \\
Calcium & $80.24 \pm 2.42$ & $80.91 \pm 1.62$ \\
Magnesium & $48.14 \pm 1.81$ & $47.33 \pm 1.37$ \\
Phosphorus & $69.93 \pm 0.23^{\mathrm{a}}$ & $66.91 \pm 0.93^{\mathrm{b}}$ \\
Actual cheese yield $(\mathrm{kg} / 100 \mathrm{~kg})$ & $19.90 \pm 0.69$ & $19.10 \pm 0.62$ \\
Pressed cheese & $17.79 \pm 0.33^{\mathrm{a}}$ & $16.43 \pm 0.40^{\mathrm{b}}$ \\
1-mo ripened cheese & & \\
Adjusted cheese yield $(\mathrm{kg} / 100 \mathrm{~kg})$ & $19.63 \pm 0.49$ & $19.34 \pm 037$ \\
Pressed cheese & $16.62 \pm 0.92$ & $15.74 \pm 0.46$ \\
1-mo ripened cheese & & \\
\hline a,b Means with different superscripts in the same row indicate statistically significant differences $(P \leq 0.05)$
\end{tabular}

between dairies.

uneven moisture distribution in cheese (Akkerman et al., 1996; Fagan et al., 2017).

The composition of the cheeses after pressing and after 1 mo of ripening did not significantly $(P>0.05)$ vary between dairy $\mathrm{A}$ and $\mathrm{B}$ (Table 6), presumably due to differences in the subsequent pressing, brining, and ripening processes carried out in the small dairies (Table 1). Therefore, although the cheesemaking process considerably differed among dairies, the resulting cheese composition remained similar, probably because the composition of milk has a bigger influence on the final cheese composition (Aldalur et al., 2019c). However, some cheese-texture traits were different depending on the intensity applied during cheesemaking process (Table 7), regardless of the cheese composition. A more intense cutting and cooking process produced cheeses that were significantly $(P \leq 0.05)$ more brittle and adhesive as well as a tendency to be stiffer with a higher fracturability (Figure 5). This could be associated with the curd-grain compaction degree in cheeses during pressing due to the different characteristics of the curd grains after cooking. Regarding microstructure, cheeses after pressing made with moderate cutting and cooking intensity were significantly $(P \leq 0.05)$ more porous, and the volume of nonglobular fat was also slightly higher (Table 7; Figure 3C and G). During ripening, the protein network became smoother (Figure 6) and the porosity of the cheeses significantly reduced $(P \leq 0.05)$, causing the compaction of the casein network for both dairies (Table 7). Additionally, fat droplets change their structural arrangement due to enzymatic reactions (Lopez et al., 2007), and all these microstructural changes

Table 6. Composition (mean $\pm \mathrm{SD}$ ) of cheeses after pressing and 1 mo of ripening for the moderate- (dairy A) and high-intensity (dairy B) processes during Idiazabal PDO cheese production $(\mathrm{n}=3)$ in small dairies

\begin{tabular}{lccccc}
\hline & \multicolumn{2}{c}{ Cheese after pressing } & & \multicolumn{2}{c}{ 1-mo ripened cheese } \\
\cline { 2 - 3 } \cline { 5 - 6 } Item & Dairy A & Dairy B & & Dairy A & Dairy B \\
\hline Fat $(\mathrm{g} / 100 \mathrm{~g})$ & $33.16 \pm 0.67$ & $32.98 \pm 0.84$ & & $33.45 \pm 0.49$ & $33.24 \pm 0.90$ \\
Protein $(\mathrm{g} / 100 \mathrm{~g})$ & $19.97 \pm 0.29$ & $20.09 \pm 0.29$ & & $22.09 \pm 0.28$ & $21.75 \pm 0.22$ \\
Moisture $(\mathrm{g} / 100 \mathrm{~g})$ & $42.43 \pm 0.78$ & $41.71 \pm 0.66$ & & $38.15 \pm 0.58$ & $39.14 \pm 0.63$ \\
Calcium $(\mathrm{mg} / \mathrm{kg})$ & $6,023 \pm 54$ & $6,084 \pm 68$ & & -1 & - \\
Magnesium $(\mathrm{mg} / \mathrm{kg})$ & $393 \pm 2$ & $384 \pm 1$ & & - & - \\
Phosphorus $(\mathrm{mg} / \mathrm{kg})$ & $4,688 \pm 28$ & $4,728 \pm 107$ & & - & \\
${ }^{\mathrm{a}, \mathrm{b}}$ Means with different superscripts in the same row and type of cheese sample indicate statistically significant \\
differences $(P \leq 0.05)$ between dairies.
\end{tabular}


Cheese after pressing

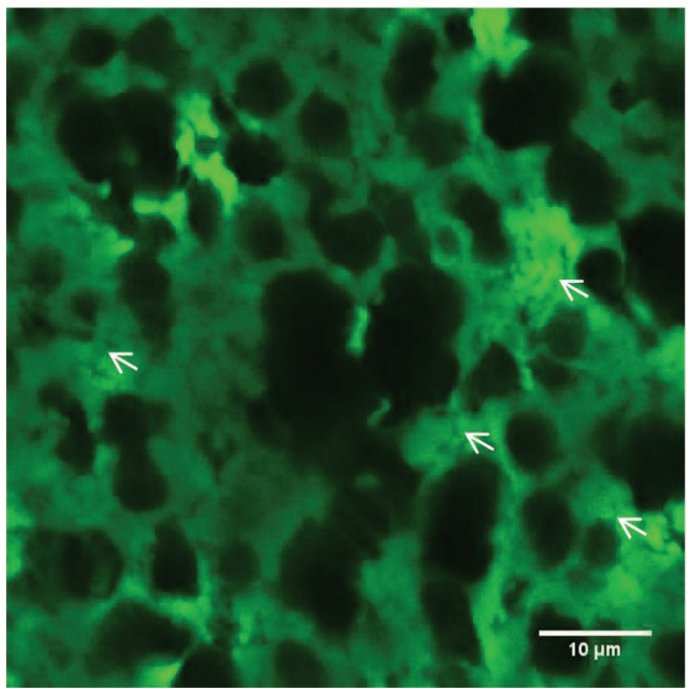

Cheese after 1-month ripening

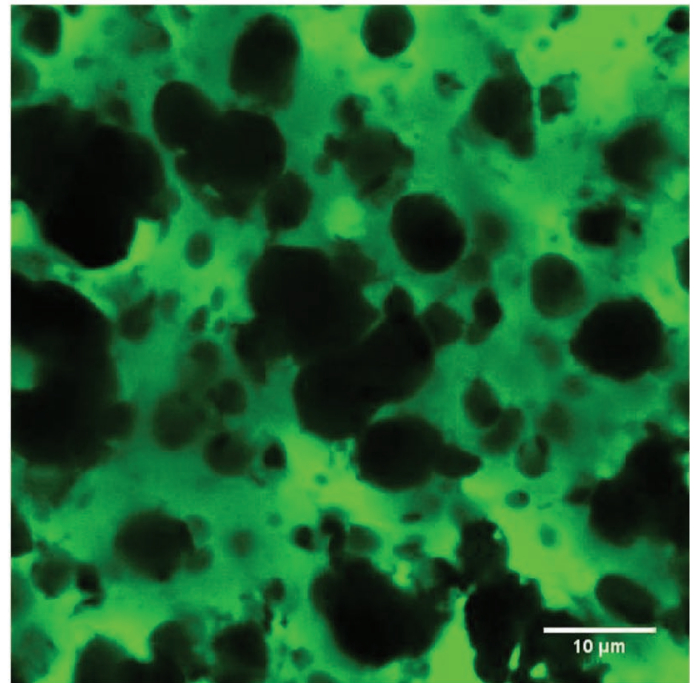

Figure 6. Confocal laser scanning microscopy images of the protein matrix (in green) of cheese after pressing (left) and cheese after 1 mo of ripening (right). Images were obtained using a $63 \times$ objective lens and digitally magnified $4 \times$. The scale bars are $10 \mu \mathrm{m}$ in length. White arrows indicate small gaps between casein aggregates in the protein matrix that disappear during ripening.

during ripening reduced the differences between dairies in 1-mo ripened cheeses. However, microstructural features were located along the latent dimension $\mathrm{t} 2(Y$ axis) related to the acidity during cheesemaking, protein and calcium recoveries, and composition-adjusted cheese yield. This could suggest the importance of the acidity during cheesemaking in the development of the microstructure and the recovery of some compounds in the cheese, as previously observed by Ong et al. (2012). In this sense, the interactions between cheese microstructure and texture, curd-grain characteristics, cheese yield, and cheesemaking settings have not been widely reported and further research should be required.

\section{CONCLUSIONS}

Cutting and cooking settings used during cheesemaking clearly affected the course of the cheese manufacture process in small dairies. The slightly increased cheese yield obtained in the moderate-intensity process was probably connected to higher milk component recoveries in cheese. Contrarily, higher fat and casein

Table 7. Values (mean $\pm \mathrm{SD}$ ) of microstructure, size, shape, and distribution traits of cheeses after pressing and after 1 mo of ripening for the moderate- (dairy A) and high-intensity (dairy B) processes during Idiazabal PDO cheese production $(\mathrm{n}=3)$ in small dairies

\begin{tabular}{|c|c|c|c|c|}
\hline \multirow[b]{2}{*}{ Item } & \multicolumn{2}{|c|}{ Cheese after pressing } & \multicolumn{2}{|c|}{ 1-mo ripened cheese } \\
\hline & Dairy A & Dairy B & Dairy A & Dairy B \\
\hline Fat droplet sphericity & $0.52 \pm 0.02$ & $0.52 \pm 0.01$ & $0.55 \pm 0.02$ & $0.54 \pm 0.01$ \\
\hline Fat droplet diameter $(\mu \mathrm{m})$ & $26.1 \pm 6.7$ & $30.4 \pm 1.4$ & $33.1 \pm 2.0$ & $37.0 \pm 4.9$ \\
\hline Volume of globular fat (\%) & $4 \pm 2$ & $3 \pm 0$ & $3 \pm 1$ & $2 \pm 0$ \\
\hline Stiffness $(\mathrm{g} / \mathrm{s})$ & - & - & $385.7 \pm 32.2$ & $440.1 \pm 54.0$ \\
\hline Brittleness (g/s) & - & - & $124.0 \pm 50.1^{\mathrm{b}}$ & $223.4 \pm 41.0^{\mathrm{a}}$ \\
\hline Hardness work $(\mathrm{g} \cdot \mathrm{s})$ & - & - & $10,778 \pm 450$ & $11,668 \pm 1,076$ \\
\hline Adhesiveness $(\mathrm{g} \cdot \mathrm{s})$ & - & - & $27.1 \pm 6.5^{\mathrm{b}}$ & $51.5 \pm 13.9^{\mathrm{a}}$ \\
\hline
\end{tabular}

\footnotetext{
${ }^{\mathrm{a}, \mathrm{b}}$ Means with different superscripts in the same row and type of cheese sample indicate statistically significant differences $(P \leq 0.05)$ between dairies.

${ }^{1}$ No measurements were carried out in these samples.
} 
losses in whey were generated when a high-intensity process was applied. This occurred due to the combined effect of a firm gel at cutting point and excessive cutting process, together with a too high-intensity cooking stage. Therefore, it is highly recommendable to cut the gel at the precise moment and to include a healing step or reduce the intensity during stirring to avoid the shattering effect that occurred regardless of the size of the curd grains after cutting. The heterogeneity of the curd-grain size distribution, together with the differences found in the size, shape, microstructure, and composition of curd grains could have an important effect on their deformation degree and compaction during pressing. Ultimately, this could be the main factor responsible for the differences observed in some microstructure and texture features of the final cheese, regardless of its composition. The results of this commercial study showed the importance of carrying out a correct cheese manufacturing process, and the consequences of the technical settings used on the whey losses and on the properties of the final cheese. The modifications of cheesemaking technical settings that are feasible and easily controllable in situ for cheesemakers are especially interesting for small producers to improve cheese yield and diminish milk component losses in the whey.

\section{ACKNOWLEDGMENTS}

The authors thank the Idiazabal PDO cheesemakers for collaborating with this study. Financial support was provided by the University of the Basque Country (UPV/EHU, Leioa, Spain; PA16/04) and the Basque Government (Vitoria-Gasteiz, Spain; IT944-16). A. Aldalur thanks the Basque Government for the research fellowship. The authors thank the technical and human support provided by SGIker (UPV/EHU, ERDF, EU). The authors have not stated any conflicts of interest.

\section{REFERENCES}

Akkerman, J. C., C. A. P. Buijsse, J. Schenk, and P. Walstra. 1996. Drainage of curd: Role of drainage equipment in relation to curd properties. Neth. Milk Dairy J. 50:371-406.

Aldalur, A., M. A. Bustamante, and L. J. R. Barron. 2019a. Characterization of curd grain size and shape by two-dimensional image analysis during the cheesemaking process in artisanal sheep dairies. J. Dairy Sci. 102:1083-1095. https://doi.org/10.3168/jds.2018 $-15177$.

Aldalur, A., M. A. Bustamante, and L. J. R. Barron. 2019c. Effects of technological settings on yield, curd, whey and cheese composition during the cheese-making process from raw sheep milk in small rural dairies: Emphasis on cutting and cooking conditions. J. Dairy Sci. 102:7813-7825. https://doi.org/10.3168/jds.2019-16401.

Aldalur, A., L. Ong, M. A. Bustamante, S. L. Gras, and L. J. R. Barron. 2019b. Impact of processing conditions on microstructure, texture and chemical properties of model cheese from sheep milk.
Food Bioprod. Process. 116:160-169. https://doi.org/10.1016/j .fbp.2019.05.003.

AOAC International. 2005. Method № 990.24. Phosphorus (total) in cheese and processed cheese products. Photometric method. Pages 94-95 in Official Methods of Analysis of AOAC International, 18th ed. W. Horowitz and G. W. Latimer Jr., eds. AOAC International, Gaithersburg, MD.

Barbano, D. M., and J. W. Sherbon. 1984. Cheddar cheese yields in New York. J. Dairy Sci. 67:1873-1883. https://doi.org/10.3168/jds .S0022-0302(84)81517-9.

Bland, J. H., A. S. Grandison, and C. C. Fagan. 2015. Evaluation of milk compositional variables on coagulation properties using partial least squares. J. Dairy Res. 82:8-14. https://doi.org/10.1017/ S0022029914000508.

Bustamante, M., F. Chávarri, A. Santisteban, G. Ceballos, I. Hernández, M. J. Miguelez, I. Aranburu, L. J. R. Barrón, M. Virto, and M. de Renobales. 2000. Coagulating and lipolytic activities of artisanal lamb rennet pastes. J. Dairy Res. 67:393-402. https://doi .org/10.1017/S0022029900004350.

De La Fuente, M. A.. B. Carazo, and M. Juárez. 1997. Determination of major minerals in dairy products digested in closed vessels using microwave heating. J. Dairy Sci. 80:806-811. https://doi.org/10 .3168/jds.S0022-0302(97)76001-6.

Everard, C. D., D. J. O'Callaghan, M. J. Mateo, C. P. O'Donnell, M. Castillo, and F. A. Payne. 2008. Effects of cutting intensity and stirring speed on syneresis and curd losses during cheese manufacture. J. Dairy Sci. 91:2575-2582. https://doi.org/10.3168/jds .2007-0628.

Everett, D. W., and M. A. E. Auty. 2017. Cheese Microstructure. Pages 547-569 in Cheese: Chemistry, Physics and Microbiology, 4th ed. P. L. H. McSweeney, P. Fox, P. Cotter, \& D. Everett, eds. Elsevier Inc, London, UK.

Fagan, C. C., D. J. O'Callaghan, M. J. Mateo, and P. Dejmek. 2017. The syneresis of rennet-coagulated curd. Pages 145-177 in Cheese: Chemistry, Physics and Microbiology, 4th ed. P. L. H. McSweeney, P. Fox, P. Cotter, \& D. Everett, eds. Elsevier Inc, London, UK.

Guinee, T. P., B. T. O'Kennedy, and P. M. Kelly. 2006. Effect of milk protein standardization using different methods on the composition and yields of Cheddar cheese. J. Dairy Sci. 89:468-482. https: //doi.org/10.3168/jds.S0022-0302(06)72110-5.

Horne, D. S., and J. A. Lucey. 2017. Rennet-induced coagulation of milk. Pages 145-177 in Cheese: Chemistry, Physics and Microbiology, 4th ed. P. L. H. McSweeney, P. Fox, P. Cotter, \& D. Everett, eds. Elsevier Inc, London, UK

Iezzi, R., F. Locci, R. Ghiglietti, C. Belingheri, S. Francolino, and G. Mucchetti. 2012. Parmigiano Reggiano and Grana Padano cheese curd grains size and distribution by image analysis. Lebensm. Wiss. Technol. 47:380-385. https://doi.org/10.1016/j.lwt.2012.01 .035 .

Ikonen, T., O. Ruottinen, and E. L. Syväoja. 1999. Effect of milk coagulation properties of herd bulk milks on yield and composition of Emmental cheese. Agric. and Food Sci. 8:411-422. https://doi .org/10.23986/afsci.5638.

ISO. 2002. Water quality - Determination of the chemical oxygen demand index (ST-COD) - Small-scale sealed-tube method. ISO 15705:2002. International Standardization Organization, Geneva, Switzerland.

ISO/IDF. 2004a. Milk - Determination of casein-nitrogen content Part 2: Direct method. ISO 17997-2:2004/ IDF 29-2:2004. International Standardization Organization, Geneva, Switzerland.

ISO/IDF. 2004b. Cheese and processed cheese - Determination of the total solids content. ISO 5534:2004/IDF 4: 2004. International Standardization Organization, Geneva, Switzerland.

ISO/IDF. 2008a. Cheese - Determination of fat content - Butyrometer for Van Gulik method. ISO 3432:2008/ IDF 221:2008. International Standardization Organization, Geneva, Switzerland .

ISO/IDF. 2008b. Processed cheese products - Determination of nitrogen content and crude protein calculation - Kjeldahl method. ISO 17837:2008/ IDF 25:2008. International Standardization Organization, Geneva, Switzerland. 
Jacob, M., D. Jaros, and H. Rohm. 2011. Recent advances in milk clotting enzymes. Int. J. Dairy Technol. 64:14-33. https://doi.org/10 .1111/j.1471-0307.2010.00633.x.

Johnston, K. A., M. S. Luckman, H. G. Lilley, and B. M. Smale. 1998. Effect of various cutting and stirring conditions on curd particle size and losses of fat to the whey during cheddar cheese manufacture in ost vats. Int. Dairy J. 8:281-288. https://doi.org/10.1016/ S0958-6946(98)00050-8.

Kammerlehner, J. 2009. Rennet cheese (Cow's milk cheese). Pages 43-624 in Cheese Technology. J. Kammerlehner, ed. Josef Kammerlehner, Freising, Germany.

Lamichhane, P., A. L. Kelly, and J. J. Sheehan. 2018. Symposium review: Structure-function relationships in cheese. J. Dairy Sci. 101:2692-2709. https://doi.org/10.3168/jds.2017-13386.

Lopez, C., B. Camier, and J. Y. Gassi. 2007. Development of the milk fat microstructure during the manufacture and ripening of Emmental cheese observed by confocal laser scanning microscopy. Int. Dairy J. 17:235-247. https://doi.org/10.1016/j.idairyj.2005.12 .015 .

Lucey, J. A. 2011. Curd syneresis. Pages 591-594 in Encyclopedia of Dairy Sciences, 2nd ed. J. W. Fuquay, P.F. Fox, and P. L. H. McSweeney, eds. Elsevier Inc, London, UK.

Ministerio de Agricultura, Pesca, y Alimentación. 1993. Orden del 30 de noviembre por la que se aprueba el Reglamento de la Denominación de Origen "Idiazabal" y su Consejo Regulador. Bol. Of. Estado 289:34591-34596.

Nájera, A. I., L. J. R. Barron, P. Ribeiro, F. Pélissier, E. Abilleira, F. J. Pérez-Elortondo, M. Albisu, J. Salmerón, J. C. Ruiz de Gordoa, M. Virto, L. Oregi, R. Ruiz, and M. de Renobales. 2009. Seasonal changes in the technological and compositional quality of ewe's raw milks from commercial flocks under part-time grazing. J. Dairy Res. 76:301-307. https://doi.org/10.1017/S0022029909004178.
Nájera, A. I., M. de Renobales, and L. J. R. Barron. 2003. Effects of $\mathrm{pH}$, temperature, $\mathrm{CaCl}_{2}$ and enzyme concentrations on the rennetclotting properties of milk: a multifactorial study. Food Chem. 80:345-352. https://doi.org/10.1016/S0308-8146(02)00270-4.

Ong, L., R. R. Dagastine, S. E. Kentish, and S. L. Gras. 2011. Microstructure of milk gel and cheese curd observed using cryo scanning electron microscopy and confocal microscopy. Lebensm. Wiss. Technol. 44:1291-1302. https://doi.org/10.1016/j.lwt.2010.12.026.

Ong, L., R. R. Dagastine, S. E. Kentish, and S. L. Gras. 2012. The effect of $\mathrm{pH}$ at renneting on the microstructure, composition and texture of Cheddar cheese. Food Res. Int. 48:119-130. https://doi .org/10.1016/j.foodres.2012.02.020.

Ong, L., R. R. Dagastine, S. E. Kentish, and S. L. Gras. 2013. Microstructure and composition of full fat Cheddar cheese made with ultrafiltered milk retentate. Foods 2:310-331. https://doi.org/10 $.3390 /$ foods 2030310 .

Riddell-Lawrence, S., and C. L. Hicks. 1988. Effect of curd healing time on stirred curd cheese yield. J. Dairy Sci. 71:2611-2617. https://doi.org/10.3168/jds.S0022-0302(88)79853-7.

van den Bijgaart, H. J. C. M. 1988. Syneresis of rennet-induced milk gels as influenced by cheesemaking parameters. Doctoral Thesis. Department of Food Science, Wageningen Agricultural University, Wageningen, the Netherlands.

\section{ORCIDS}

Ane Aldalur @ https://orcid.org/0000-0002-9232-2052

María Ángeles Bustamante (ㄱ https://orcid.org/0000-0001-5067-6074

Jesús Salmerón (® https://orcid.org/0000-0001-5438-6656

Luis Javier R. Barron @ https://orcid.org/0000-0002-2563-1082 